\title{
Content / Inhalt
}

7 Carolin Behrmann

Figura Infamante

Schandbilder und die Ethik der oeconomia

29 Gherardo Ortalli

Pittura Infamante

Practices, Genres and Connections

49 Matteo Ferrari

Prime pitture d'infamia nei comuni italiani

Immagini come documenti, immagini come fatti

75 Karl Härter

Images of Dishonoured Rebels and Infamous Revolts

Political Crime, Shaming Punishments and Defamation in

the Early Modern Pictorial Media

103 Wolfgang Brückner

Bild-Ehre, Bild-Schande, Bild-Ängste

Einstige Kommunikationsweisen und heutige Diskursverkürzungen

119 Giuliano Milani

The Ban and the Bag

How Defamatory Paintings Worked in Medieval Italy 
141 Thomas Ricklin

"more cuiusdam Cioli et aliorum infamium"

On Dante's Refusal to Return Home and How He Became Florentine Again

169 Felix Jäger

Sovereign Infamy

Grotesque Helmets, Masks of Shame and the Prehistory of Caricature

193 David Freedberg

From Defamation to Mutilation

Gender Politics and Reason of State in Africa

217 Hana Gründler

„Ein Kampf mit der Sicht.“

Antlitz, Kunst und Erhabenes bei Emmanuel Levinas

239 Piyel Haldar

From Dignity to Shame

$\mathrm{X}$-rays and Legal Persona

265 Acknowledgements / Dank

267 Index / Personenregister

270 Picture Credits / Bildnachweise 